Héctor Libreros Cortez ${ }^{1}$

University of Veracruz, Research Institute in Education, Mexico

Iris Schrijver

University of Antwerp, Department of Applied Linguistics, Translators and Interpreters, Belgium

\title{
Advantages and Challenges of Online Translation Teaching and Learning During the COVID-19 Pandemic: A Mexican Case Study ${ }^{2}$
}

Summary: This qualitative article analyzes the advantages and challenges that Mexican university professors and students experienced with online translation teaching and learning during the August-December 2020 semester. Data was collected using online semi-structured interviews and non-participant observations involving 39 English language students and two translation professors from the School of Languages and Literatures of the Autonomous University of Queretaro. The findings show that some students could successfully manage distance education due to their organizational and self-learning skills, commitment, motivation, and proper internet access. However, most students faced various technological, didactical, and health issues that interfered with their learning process, which increased their desire to return to regular classes at the university as soon as possible.

Keywords: students, professors, translation, distance teaching, online learning.

\section{Introduction}

Changes in the social and geographical context regularly impact educational practices. How-

1 hectorlibreroscortez@gmail.com

2 This paper results from the joint doctoral thesis La construcción de los saberes en traducción: el caso de la Universidad Autónoma de Querétaro (University of Veracruz, México \& University of Antwerp, Belgium). This project has been funded by a PhD scholarship (CVU: 702954) from the Consejo Nacional de Ciencia y Tecnología (Spanish for National Council of Science and Technology; abbreviated CONACYT). ever, the COVID-19 pandemic has caused many profound adjustments, transitions, and innovations inside and outside the classroom worldwide. Since its outbreak in December 2019, the coronavirus has significantly affected the educational activities of different entities (Dietz \& Mateos-Cortés, 2021) because both institutions and individuals have had to reformulate their ways of teaching and learning. The COVID-19 pandemic showed the Global North and Global South addressing teaching and learning challenges from different perspectives

Copyright (C) 2021 by the authors, licensee Teacher Education Faculty University of Belgrade, SERBIA.

This is an open access article distributed under the terms of the Creative Commons Attribution License (CC BY 4.0) (https://creativecommons.org/licenses/by/4.0/), which permits unrestricted use, distribution, and reproduction in any medium, provided the original paper is accurately cited. 
(Afolabi \& Oyetoyan, 2021). Although in different Global North countries, language, translation, and interpreting classes continued through mass media (Afolabi \& Oyetoyan, 2021; Gerber, Hlavac, Shepherd, McIntosh, Avella-Archila \& Cho, 2021; Manès-Bonnisseau, 2020), lockdown ultimately halted teaching and learning practices in other nations. For example, Afolabi and Oyetoyan (2021) report that on the African continent, educators and students faced challenges related to technology, internet, and electricity access and the lack of technological skills. These challenges are similar to other countries, for example, Mexico, as shown in the case study presented in this paper.

In Mexico, the three first cases of COVID-19 were confirmed at the end of February 2020. Two of them were detected in Mexico City and the third one in the State of Sinaloa. By March 11, 2020, 11 cases were reported in the country. Three days later, the Ministry of Education (Spanish: Secretaría de Educación Pública, SEP) established that in all Mexican schools, the Easter holidays would be brought forward and extended from March 23 to April 20, 2020 (Suárez; Suárez-Quezada; Oros-Ruiz \& Ronquillo de Jesús, 2020). By March, 26, 2020, “non-essential activities were suspended, except those related to security, health, energy and cleaning services" (Suárez; Suárez-Quezada; Oros-Ruiz \& Ronquillo de Jesús, 2020: 465).

This situation made the Mexican Ministry of Education take some educational measures to remediate the absence of face-to-face classes. By March 23, 2020, the learning at home (Spanish: Aprende en casa) program started its emissions through television (SEP, 2020a). Learning at home is a television-radio-online education initiative (SEP, 2020a; $2020 \mathrm{~b})$ that has been implemented in primary and secondary education for students to conclude the last two academic years (2019-2020 and 2020-2021). This initiative "managed to provide some audiovisual resources to complement the official textbook so that children, along with their parents, in their homes could receive lessons organised by the traditional subjects of the national curriculum" (Dietz \& Mateos-Cortés, 2021: 3). Unfortunately, the lack of access to electricity and the internet of a significant part of the Mexican population has reduced the merit of this initiative.

At the university level, Mexican institutions moved from traditional face-to-face to online classes to provide emergency remote teaching and learning. In particular, the Autonomous University of Querétaro (Spanish: Universidad Autónoma de Querétaro, UAQ), which is the most important public university in the state of Queretaro, Mexico, has been providing distance learning in virtual environments from the beginning of 2020 up to now. This decision has prompted modifications in the curriculum of various graduate and undergraduate programs and has impacted the lives of students and professors.

This article aims to analyze the positive and negative experiences of Mexican university students and professors with online translation classes during the August-December 2020 semester. It will provide insights on the adaptations in translation teaching and learning forced by and experienced during the COVID-pandemic, which can be compared and contrasted with reports from other parts of the world (e.g., Afolabi \& Oyetoyan, 2021). Sharing participants' experiences will lead to a better understanding of the differences in contexts and personal experiences.

\section{Literature review}

The Mexican translation teaching and learning context is rather singular compared to other countries because public universities offer only six graduate and undergraduate translation and interpretation programs (Libreros-Cortez \& Ortiz-Lovillo, 2021). In contrast, 15 undergraduate programs in foreign languages have specializations or particular interest in translation (Libreros-Cortez \& OrtizLovillo, 2021). For example, the UAQ Bachelor's De- 
gree in English, the object of the case study in this paper, is an on-campus undergraduate program in which students study linguistics, translation, pedagogy, and literature (Universidad Autónoma de Querétaro, n. d.).

Similarly, as Afolabi and Oyetoyan (2021) have shown for the African continent, the preCOVID-19 training in the UAQ Bachelor's Degree employed the traditional teaching method. In other words, the educational process used to be faceto-face inside the classroom. Students used to learn theory and carry out translation exercises with the professors' help during translation classes. The use of online tools was limited, although one of the two professors in the case study mentioned he would use Google classroom for activities and homework. The assessment used to be both continuous and summative, and students would have exams throughout the semester.

During the COVID-19 pandemic, the UAQ undergraduate program implemented online teaching, which can be defined "as faculty-delivered instruction via the Internet [including] real-time (synchronous) and anytime, anywhere (asynchronous) interactions" (Poe \& Stassen, 2002: 5), as well as Elearning, i.e., the use of electronic resources during the educational process (Pym, 2004). Most of the translation classes at UAQ were synchronous and developed through Zoom during the August-December 2020 semester. In contrast, students' activities and

Table 1. Benefits of online teaching and learning

\begin{tabular}{|c|c|}
\hline \multicolumn{1}{|c|}{\begin{tabular}{|} 
Advantages of Learning Online \\
"Student-centered learning
\end{tabular}} & $\begin{array}{c}\text { Advantages of Teaching Online } \\
\text { Collaborative learning }\end{array}$ \\
\hline Easy access to global resources & $\begin{array}{c}\text { Provide ideas and techniques to implement in traditional } \\
\text { courses }\end{array}$ \\
\hline Experiential learning through multimedia presentations & Professional satisfaction \\
\hline Accessible for non-traditional students & Instructor convenience" \\
\hline Draws on student interest in online learning & \\
\hline
\end{tabular}

Source: Elaborated by the authors based on Poe and Stassen (2002: 6-7) homework were required to carry out were asynchronous and uploaded to Google Classroom. Students also used Gmail and WhatsApp, the latter known for facilitating the proximity between individuals (Scribano, 2017) and which, as found in the present study, helped to clarify doubts with the professors about assignments, deadlines, exercises, and projects.

This educational situation is a crude testament to Pym's pre-pandemic observation that "the incorporation of e-learning into translator training might be regarded as the way of the future" (2004: 3). Although online teaching and learning was around in the pre-pandemic era in some translation institutions worldwide, the COVID-19 pandemic has forced universities to pay considerably more attention to distance education and didactic resources to continue teaching and learning (Hubscher-Davidson \& Devaux, 2021). Online translation education and e-learning did not only help to continue educational processes during COVID-19, but they have also addressed the need for future translators to develop competencies associated with new technologies and the professional field requirements. Pym (2004) has pointed out that e-learning may be helpful to translation students to master technological-communicative skills, as well as to implement tandem learning between academic peers and to deal with students' demands related to online education. Similarly, Poe and Stassen (2002) mention certain general advantages of online education, as shown in Table 1.

Source: Elaborated by the authors based on Poe and Stassen (2002:6-7) 
Despite its merits, Pym (2004) and Poe and Stassen (2002) also recognize several online teaching and learning challenges. Pym (2004) states that E-learning is not a panacea and highlights issues such as high resource investment, student distress, problems of unequal technical and linguistic competencies due to heterogeneous learning communities, and waning motivation. Poe and Stassen (2002: 9) mention challenges associated with "Familiarity with the online environment [;] Capacity to use the medium to its advantage [;] Being available to students on an extended basis electronically [;] Providing quick responses and feedback to students."

\section{Aim and methodology}

This article analyzes the advantages and challenges experienced by Mexican university professors and students with online translation teaching and learning during the August-December 2020 semester. This study follows a qualitative approach, which "is generally associated with the interpretivist position” (Saldanha \& O'Brien, 2014: 22) and acknowledges the researcher's perceptions during the data analysis. It is also interested in social-cultural actions and practices in collective spaces such as academic institutions (Holliday, 2015), in this case, the Autonomous University of Queretaro.

The present inquiry is a case study because it profoundly analyzes people with a singular identity and unique characteristics that develop in a particular context (Albert, 2007; Simons, 2011; Pearson, 2015). This research does not aim to generalize, but to provide an outlook of Mexican situation. The case study involved 39 English language students and two translation professors from the School of Languages and Literatures of the Autonomous University of Queretaro. Analyzing this didactic situation is meaningful for two reasons. The first is to yield more insight into Mexican translation professors and students' experiences in light of the lack of research about Translation Didactics in the country.
The second is to identify how the participants faced the teaching and learning process during the COVID-19 pandemic. Their experiences could be compared to others from different contexts to analyze present and future challenges.

A non-probability sampling method was selected for choosing the translation courses and corresponding students and teachers to be studied (Lavrakas, 2008; Taherdoost, 2016). This type of sampling is frequently employed in qualitative case studies (Lavrakas, 2008). Moreover, convenience sampling (Lavrakas, 2008; Taherdoost; 2016) was chosen because the researchers developed good online relationships with the translation professors, facilitating a closer and more personal approximation with their students. During the online fieldwork, informed consent was asked from the participants to present their research details and protect their privacy and rights (Lavrakas, 2008b; Saldanha \& O’Brien, 2014; Simons, 2011).

According to Pearson (2015), case studies can employ data from different resources, such as interviews, various documents, and classroom observations. The data for the present study were collected online using 41 individual semi-structured interviews (39 students and two professors) and 67 nonparticipant classroom observations (160 hours in total). The classes observed were four: Introduction to Translation (first semester), Technologies Applied to Translation (third semester), Legal Translation (fifth semester), and Medical Translation (seventh semester). These research methods were selected to contrast the participants' discourse and actions.

The data collected from the classroom observations were transcribed manually, whereas the semi-structured interviews were transcribed with the help of the web app oTranscribe. The data were subsequently coded and classified into analytical categories related to the participants' teaching and learning processes. Finally, the data were analyzed with the ATLAS.ti software following Holliday's (2015) analytical approach. 


\section{Results}

The findings of the case study will be discussed in three sections. First, the general educational changes adopted in the UAQ undergraduate degree will be outlined. This information will provide the contextual framework to interpret the positive experiences of the professors and students with online translation teaching and learning during the August-December 2020 semester, which will be presented subsequently. Finally, the challenges of the teaching-learning process of the informants will be discussed.

\section{Educational changes during the teaching and learning process}

Findings reveal that during to COVID-19 pandemic, professors and students faced different educational changes. First, as in many other contexts worldwide, the teaching mode was modified, shifting from face-to-face to distance education. Professors started to apply collaborative learning (Poe \& Stassen, 2002) and translation projects during the classes. These ways of teaching are commonly used in translation training, as shown by Hurtado (2019). Secondly, assessment practices also changed, more particularly involving a reduction of the number of exams. The professors motivated this decision to make students feel calm and comfortable during the new educational process. Learners appreciated this decision because translation projects and the reduction in exams helped them plan their learning activities better because they could use the exams time to accomplish activities from other courses.

The professors who participated in this study expressed that at the beginning of the COVID-19 pandemic, it was tough for them to deal with the educational changes. However, the situation improved a little over time. One of the professors did not give details about his online education skills. Nevertheless, the other educator mentioned he was familiarized with online teaching because he used to work at a private university where his translation classes were virtual. Moreover, the Autonomous University of Queretaro's capacitation course strengthened his online teaching to face the distance education challenges. During this training, he learned that he must promote student autonomy and student-centered learning. He added that the course emphasized the idea of giving freedom to students to learn. Therefore, he focused on guiding students during the exercises and helping them with their doubts, but learners have to be in charge of the translation projects, considering that online learning emphasizes active and reflective student participation (Poe \& Stassen, 2002). Although both professors recognized it was necessary to let students take an active role in learning, it was essential to establish projects and assignment deadlines to prepare learners to deal with professional translator requirements.

Hubscher-Davidson and Devaux (2021) point out that there is a significant difference between well-planned online learning experiences and emergency remote teaching online. This discrepancy could also be observed in students' comments regarding the unexpected change of education mode and its rather haphazard implementation. Participants explained that, in contrast to the good preparation experienced in the pre-pandemic semesters, when the activities and schedules were well planned, the virtual classes at the beginning of the COVID-19 pandemic were somewhat disorganized. It seemed that neither the institution nor the professors and students were ready to change their teaching and learning practices.

Following the shift from face-to-face to online education, students detected that the learning activities became more individual, forcing them to cope with translation exercises independently. This way of learning has been helpful for students to work alone, as many translators do. 


\section{Advantages of online education according to the students}

According to learners, the new online translator education had several advantages. They did not have to travel long distances to the campus every day, which helped them save money and time. The participants even expressed that some B.A. classes could be offered permanently online given their theoretical approach; the same was said about translation technology courses since their main objective is to learn about informatics programs applied in translation practice. Besides, the new modality lets them learn at their own pace and work more closely with technology. By using digital resources, learners started to interact with their future professional reality because of the growing ICT integration in different work areas (Galán-Mañas, 2009).

A small group of students recognized that educational changes during the learning process were less challenging for them because of their learning styles (visual and aural) (Gómez, Jaimes \& Severiche, 2017) and their individualist introvert personalities, helped them to adapt to online education. They could successfully manage distance education owing to their organizational and self-learning skills, commitment, and motivation. Moreover, these learners have good economic conditions and proper internet access to study comfortably. These characteristics could make them suitable for blended learning, as Galán- Mañas (2009) shows when analyzing the advantages and disadvantages of distance learning. Figure 1 summarizes the main advantages of online learning reported by the students.

Students' positive perceptions regarding online education are related mainly to comfort and academic and personal organization. In other words, distance learning is associated with flexibility (Galán-Mañas, 2009). Academically, participants considered autonomy and self-learning promotion as the central favorable aspects of this way of learning. They believed the new modality let them learn at their own pace and disengage from the professors who supervise learning progress. However, according to the learners, virtual training has some weak points, as mentioned in the following section.

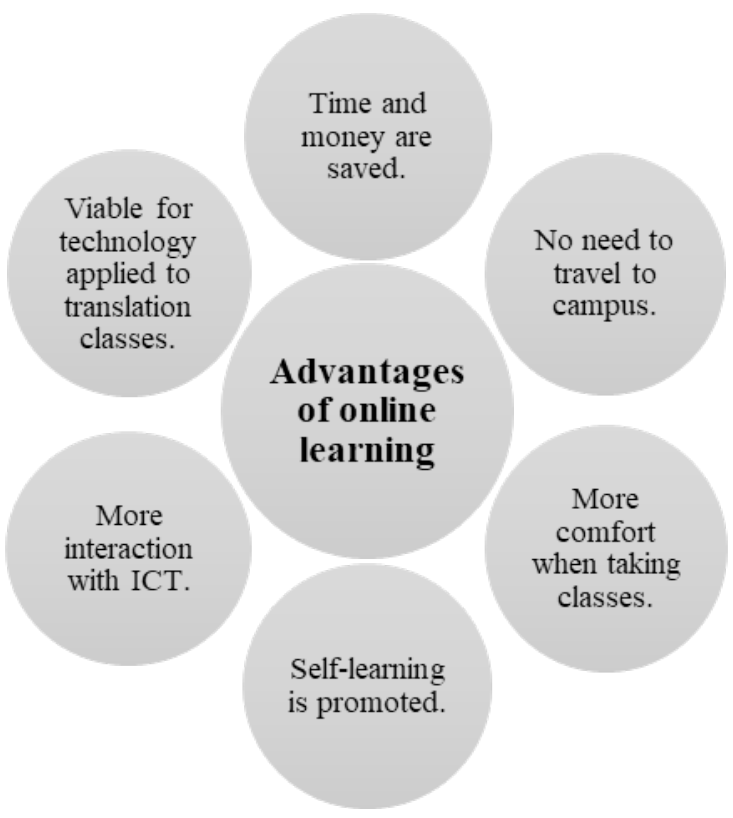

Figure 1. Advantages of online learning

Source: Elaborated by the authors based on the participant students' opinions.

\section{Challenges of online education experienced by the participants}

The data showed that most of the participants had developed negative perceptions about online education and health problems that interfered with their teaching and learning process. For this reason, they clearly expressed their desire to return to regular face-to-face classes at the university as soon as possible.

The professors mentioned that in light of the online teaching mode, they had to develop more digital educational resources, such as tutorials, PowerPoint presentations, videos, and worksheets for translation classes. For this reason, they had to spend more time preparing, creating, recording, and editing every educational resource. 
Most of the learners emphasized connectivity issues. This challenge could be observed during classes because students switched off for different reasons, such as internet or electricity problems, functionality problems with devices, or connectivity problems caused by the weather. This situation resembles the one presented by Afolabi and Oyetoyan (2021), where African students and professors also reported challenges associated with internet connectivity and electricity, common issues in the Global South. Additionally, some learners affirmed they did not have an idoneous place to study. These disadvantages affected students' learning and may explain why the generally positive European experiences during the lockdown, such as those presented by Manès-Bonnisseau (2020), could not be observed in this case study.

Some learners consider the School of Languages and Literatures the appropriate place to learn because it was built for that purpose. They did not feel comfortable working at home because they felt the online learning environment had invaded their intimacy, eliminating the barrier between their private sphere and university life. Both students and professors highlighted the perception that due to the lockdown and access to technology and the internet, people expected they were available to deal with academic matters all day long.

Students expressed that online learning can be complex because they had to deal with procrastination temptations at home, for example, cellphones, video games, music, and social media. During the classroom observations, it was possible to observe that some students ate, drank hot beverages, talked with family members, or were even cooking.

Some learners recognized they were less responsible with homework and activities during the COVID-19 pandemic, partly due to the aforementioned procrastination. They did not plan their activities properly and wasted time. This disorganization became visible when they had to submit Google
Classroom assignments which contained numerous errors in the exercises and translation tasks and resulted in lower grades.

Students felt classes through Zoom were more cognitively tricky because they had to be alone in front of the computer for many hours. According to learners, classes turned repetitive due to the lack of contact with classmates to interact and share ideas, doubts, and feelings during the learning process. During the classroom observations, some students indeed looked bored, tired, or even sad. Other learners also mentioned emotional problems related to demotivation, stress, and anxiety.

Finally, professors and students reported health problems due to continuous computer use and being seated all day. The most common symptoms were eye and back pain, as well as headaches. The data show the teacher malaise derived from the COVID-19 pandemic and the change of educational mode. In our case, teacher malaise manifested as eye problems in one educator, and stress in the other professor. However, Cordié (1998: 69) indicates that disorders connected to stress "can range from simple emotional manifestations to somatic disorders: cardiovascular diseases, gastritis, hemorrhagic rectocolitis, asthma, dermatitis, as well as migraines, blood pressure, depression... Therefore, teacher unrest is not always associated with students.

Figure 2 summarizes the main challenges posed by online education that were reported by the students.

The number of challenges of online education exceeds the number of advantages examined in the previous section. However, this does not mean that face-to-face education is better or worse than online teaching and learning, but rather that most students in this case study favor the traditional educational mode due to didactic, economic, and health issues. 


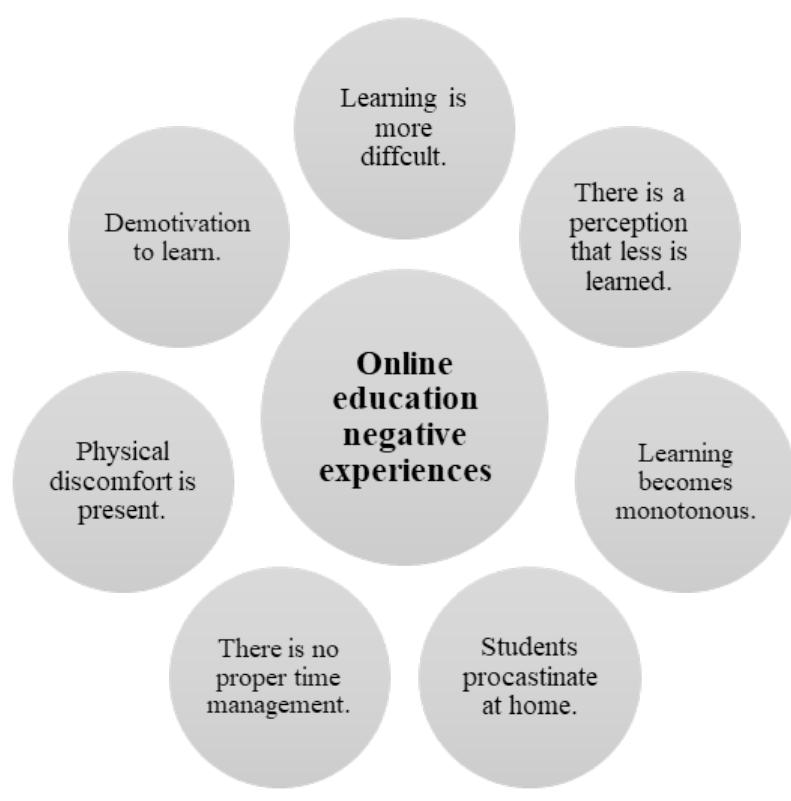

Figure 2. Negative experiences regarding online education

Source: Elaborated by the authors based on the participant students' opinions.

\section{Conclusion}

All changes experienced by the participants in this case study are related to the adaptation to the new online teaching and learning environment. Some of them emphasized the didactic measures, such as reduction of the number of exams, the promotion of student-centered learning and student autonomy, the conceptualization of the teacher as a facilitator, and the implementation of translation projects. However, others highlighted the differences among students, such as their planning skills, economic conditions, and proper internet access, which influenced online learning.

The advantages of online learning reported by the students are connected mainly to their wellbeing. Another positive perception concerned more experience with ICT and the possibility to apply autonomous learning. Although the participants recognized several advantages of the virtual mode, neg- ative perceptions about online education were predominant. These challenges were related primarily to didactic issues and personal characteristics, and the discomfort of working remotely.

The case study shows that different circumstances and elements may promote or interfere with students' learning processes. Nevertheless, some learners firmly believe that it is also essential for students to make personal changes, become more autonomous, explore beyond what the virtual classroom offers and remember that the professor only guides the learning process. In other words, they are conscious about their learning and show signs of metacognition, understood as "the knowledge and the active monitoring of one's own cognitive processes" (Zulkiply, 2016:1).

These findings inspire us to think about some beneficial changes to be applied in online translation teaching in the conditions of pandemics:

1. Focus the attention on students' development and promote students' self-learning.

2. Do not saturate learners with online activities and homework that are not meaningful to them.

3. Try to implement warm-up activities.

4. Motivate learners to propose texts or topics to translate in class according to their level.

5. Emphasize to students that being responsible is a quality needed for becoming a professional translator.

6. Take into account the socio-educational context and the students' conditions.

This last point is important because "in this planetary era we have to situate everything in the planetary complex and context. Learning about the world as [the] world has become a vital and intellectual necessity." (Morin, 1999: 13). The experiences presented in this paper reflect features of a situated reality. These points could be contrasted to other contexts with similar characteristics to examine how the COVID-19 pandemic has transformed the curriculum and the lives of students, professors, researchers, and parents. 


\section{References}

- Afolabi, S. \& Oyetoyan, O. I. (2021). Charting a new course for translator and interpreter training in Africa: Lessons from the COVID-19 experience in selected countries. The Journal of Specialised Translation, 36, 327-350.

- Albert, M. J. (2007). La investigación educativa: claves teóricas. Madrid: Editorial Mc Graw Hill.

- Galán-Mañas, A. (2009). La enseñanza de la traducción en la modalidad semipresencial (doctorial dissertation). Barcelona: Universitat Autónoma de Barcelona, Department de Traducció i d' Interpretació.

- Gerber, L., Hlavac, J., Shepherd, I., McIntosh, P., Avella-Archila, A. \& Cho, H. (2021). Stepping into the Future: Virtual Reality Training for Community Interpreters Working in the Area of Family Violence. The Journal of Specialised Translation, 36, 252-272.

- Gómez, E. M., Jaimes, J. C. \& Severiche, C. A. (2017). Estilos de aprendizaje en universitarios, modalidad de educación a distancia. Revista Virtual Universidad Católica del Norte, 50, 383-393.

- Dietz, G. \& Mateos-Cortés, L. S. (2020). Mexican intercultural education in times of COVID-19 pandemic. Intercultural Education, 32 (1), 100-107. DOI: 10.1080/14675986.2020.1843895

- Holliday, A. (2015). 3. Qualitative Research and Analysis. In: Phakiti, A. \& Paltridge, B. (Eds.). Research Methods in Applied Linguistics. A Practical Resource (49-62). London: Bloomsbury Academic.

- Hubscher-Davidson, S. \& Devaux, J. (2021). Teaching Translation and Interpreting in Virtual Environments. The Journal of Specialised Translation, 36, (184-192).

- Lavrakas, P. J. (2008a). Convenience Sampling. In: Encyclopedia of survey research methods (149-149). Los Angeles-London-New Delhi-Singapore-Wahington DC: SAGE Publications, Inc.

- Lavrakas, P. J. (2008b). Informed consent. In: Encyclopedia of survey research methods (336-337). Los Angeles-London-New Delhi-Singapore-Wahington DC: SAGE Publications, Inc.

- Libreros-Cortez, H. \& Ortiz-Lovillo, M. P. (2021). La formación en traducción en México: documentación y análisis de los programas de estudio. Entreculturas. Revista de traducción y comunicación Intercultural, 11, 85-104. DOI: 10.24310/Entreculturasertci.v1i11.12105

- Manès-Bonnisseau, C. (2020). Éditorial. Courriel européen des langues: le magazine du point de contact du CELV en France, 43, 1-3.

- Morin, E. (1999). Seven complex lessons in education for the future. France: UNESCO.

- Pearson, C. (2015). 7. Case studies. In: Phakiti, A. \& Paltridge, B. (Eds.). Research Methods in Applied Linguistics. A Practical Resource (119-136). London: Bloomsbury Academic, Chapter 7.

- Poe, M. \& Stassen, M. (2002). Teaching and Learning Online: Communication, Community, and Assessment: A Handbook for UMass Faculty. Amherst, Mass: University of Massachusetts, S. D.

- Pym, A. (2004). E-learning in translator training. In: Rega, L. \& Magris, M. (Eds.). Übersetzen in der Fachkommunikation - Comunicazione specialistica e traduzione (161-173). Tübingen: Gunter Narr.

- Saldanha, G. \& O’Brien, S. (2014). Research Methodologies in Translation Studies. London \& New York: Routledge Taylor \& Francis Group.

- Secretaría de Educación Pública (2020a). Boletín No. 80 Fortalece SEP programa Aprende en Casa mediante sitio web especializado en educación básica. Retrieved August 16, 2021. from www: https://www.gob.mx/sep/ 
es/articulos/boletin-no-80-fortalece-sep-programa-aprende-en-casa-mediante-sitio-web-especializado-eneducacion-basica?idiom $=\mathrm{es}$

- Secretaría de Educación Pública (2020b). Boletín No. 118 No se paralizó el Sistema Educativo ante la pandemia de COVID-19; regresará a clases fortalecido: Esteban Moctezuma Barragán. Retrieved May 15, 2020. from www: https://www.gob.mx/sep/articulos/boletin-no-118-no-se-paralizo-el-sistema-educativo-ante-lapandemia-de-covid-19-regresara-a-clases-fortalecido-esteban-moctezuma-barragan?idiom=es

- Scribano, A. (2017). Miradas cotidianas: el uso de Whatsapp como experiencia de investigación social. Revista Latinoamericana de Metodología de la Investigación Social, 7, 8-22.

- Simons, H. (2009). El estudio de caso: teoría y práctica. Madrid: Morata.

- Suárez, V., Suarez-Quezada, M., Oros-Ruiz, S. \& Ronquillo De Jesús, E. (2020). Epidemiología de COVID-19 en México: del 27 de febrero al 30 de abril de 2020 [Epidemiology of COVID-19 in Mexico: from the 27th of February to the 30th of April 2020]. Revista clinica española, 220, 463-471. DOI: 10.1016/j.rce.2020.05.007

- Taherdoost, H. (2016). Sampling Methods in Research Methodology; How to Choose a Sampling Technique for Research. International Journal of Academic Research in Management (IJARM), 5, 18-27.

- Universidad Autónoma de Queretaro-Facultad de Lenguas y Letras (s.f.). Plan Curricular de la Licenciatura en Lenguas Modernas en Inglés. Retrieved July 29, 2021. from www: fll.uaq.mx/docs/MC_ingles.pdf

- Zulkiply, N. (2006). Metacognition and its relationship with students' academic performance. Universiti Teknologi Malaysia Institutional Repository. 


\section{Ектор Либрерос Кортес}

Универзитет у Веракрусу, Институт за истраживање образовања, Мексико

\section{Ирис Шрајвер}

Универзитет у Антерверпену, Одсек за примењену лингвистику, преводиоце и тумаче, Белгија

\section{ПРЕДНОСТИ И НЕДОСТАЦИ ОНЛАЈН-НАСТАВЕ ПРЕВОБЕЊА ЗА ВРЕМЕ ПАНДЕМИЈЕ ВИРУСА КОРОНА: СТУДИЈА СЛУЧАЈА ИЗ МЕКСИКА}

У раяу се анализирају йреgностии и изазови које су мексички универзитетеиски иррофесо-

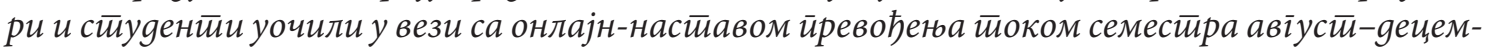

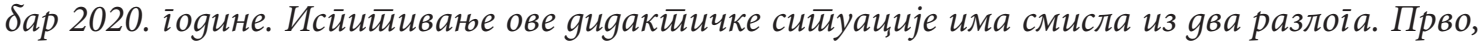

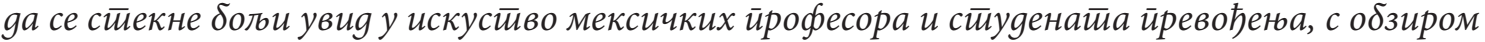

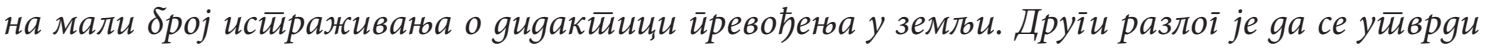
како су учесници овоі истираживаға оживели ирроцес йоgучавањ и ичењь тиоком йандемије вируса корона. Њихова искусивва могуу се уйореgити са оним из gруіачијих кониекксйа како би се анализирали саяашғьи и буgући изазови.

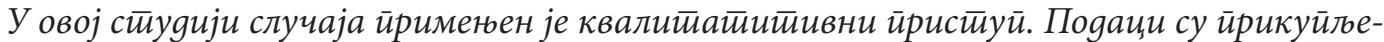

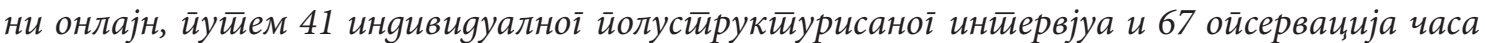
без учесника (укуйно 160 сайи), у којима је учестивовало 39 стиуденатиа енїлеской језика и gва иррофесора йревођеюа са Факулиетеиа за стиране језике и књижевносиии ирри Ауйономном универзитиетиу Керетиаро (енї. Autonomous University of Queretaro). Ове исирраживачке метиоgе су оgабране gа би се уйоредили gискурс и йосииуйци учесника у истираживаюуу.

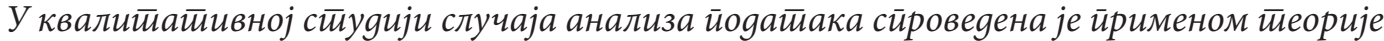
из Пеgаїоіије йревођењьа, која се фокусира на онтајн-насииаву и учене, е-ученье и настиаву ирревођењь у Мексику. Подаци су коgирани и класификовани у аналитиччке катетіорије, које

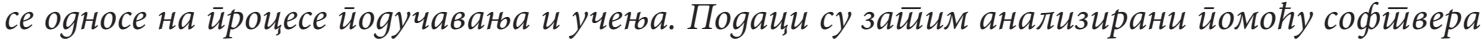
ATLAS.ti. Налази истираживаюа размайрају се у тири олелька. Прво, уойшиеено су навеgене

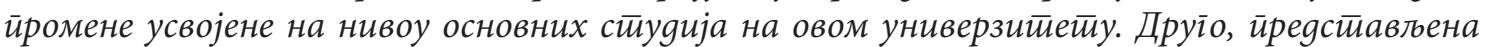

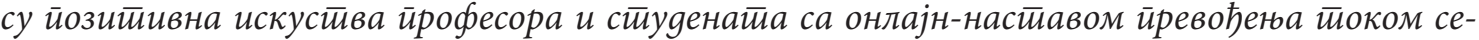
месира авіусси-децембар 2020. їодине. На крају, разматирају се изазови са којима су се исииийаници сусретиали у ииоку онлајн-часова.

Налази истираживаюа йоказују gа су се йоком йандемије вируса корона иррофесори и сииуденити суочавали са различитиим образовним ироменама. Прво, као и у мноїим gруїим земљама широм светиа, модификован је начин йоgучаваюа, ирретаском са настиаве уживо у учионици на образоваюе на gалину. Професори су йочели gа ирримењују колабораииивно учење (Poе \& Stassen, 2002) и увели су ирревоgилачке ирројекиее. Према сииуяеніиима, нова фор-

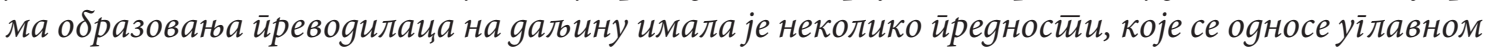

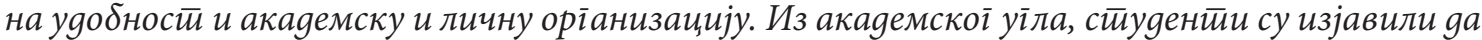

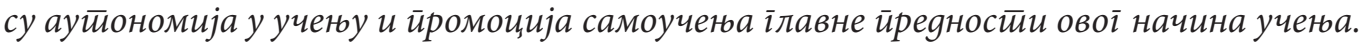




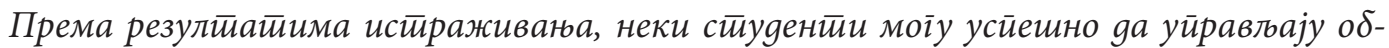
разованем на далину захваљујући својим оріанизационим вешииинама, вешитинама само-

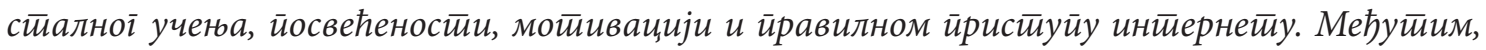
већина учесника исказала је неїаиивне стиавове о онлајн-образовану и здравстивеним ироблемима који су ометиали юихов ирроцес учеюа. Из йоі разлоїа јасно су изразили жельу gа се

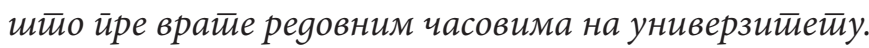

Ови налази нас йоgсиичу gа размишььамо о ирроменама које су корисне за онлајн-образоване и доживойно образоваюе и gа осмислимо нове начине за йобольиане онлајн-

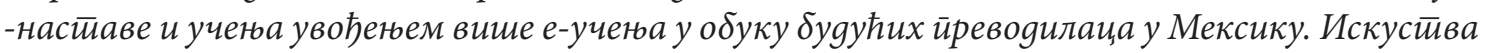

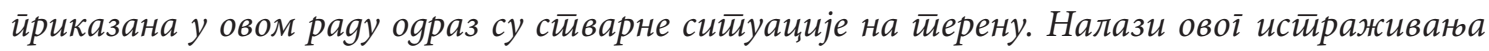

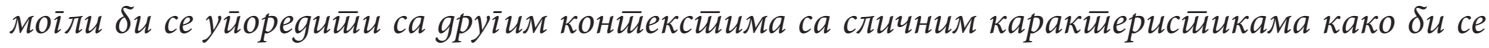
исииитало како је йандемија вируса корона ирроменила настиавни йлан и ирроірам и живоие

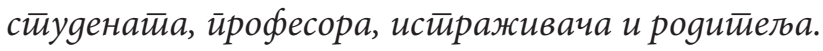

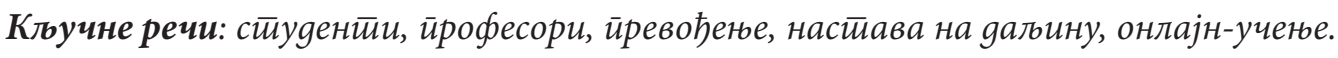

